\title{
HUBUNGAN FAKTOR RISIKO DENGAN KEJADIAN PTERYGIUM DI POLIKLINIK MATA BADAN LAYANAN UMUM DAERAH RUMAH SAKIT UMUM CUT MEUTIA KABUPATEN ACEH UTARA TAHUN 2015
}

\author{
Dara Phonna Ardianty ${ }^{1 *}$, Nora Maulina ${ }^{2}$ \\ $1^{*}$ Mahasiswa Program Studi Pendidikan Dokter, Fakultas Kedokteran, Universitas \\ Malikussaleh, Jl. H. Meunasah, Uteunkot, Cunda, Lhokseumawe, Provinsi Aceh, 24351 \\ 2 Bagian Fisiologi Fakultas Kedokteran, Universitas Malikussaleh, Jl. H. Meunasah, Uteunkot, \\ Cunda, Lhokseumawe, Provinsi Aceh, 24351 \\ *Corresponding author : phonna.dara@yahoo.com
}

\begin{abstract}
Abstrak
Pterygium merupakan penyakit mata bagian eksternal yang umum terjadi secara global. Pterygium dapat menyebabkan terjadinya astigmatisme serta menimbulkan gangguan lain seperti menurunnya tajam penglihatan, iritasi kronik, inflamasi rekuren, penglihatan ganda, serta gangguan pergerakan bola mata bahkan kebutaan. Penelitian ini bertujuan untuk mengetahui hubungan faktor risiko dengan kejadian Pterygium di Poliklinik Mata BLUD RSU Cut Meutia, Kabupaten Aceh Utara tahun 2015. Jenis penelitian ini adalah observasional analitik dengan pendekatan kasus kontrol. Penelitian ini dilaksanakan di bulan September 2015-Maret 2016 dan jumlah sampel sebanyak 30 pasien pterygium dan 30 pasien non-pterygium. Analisis data menggunakan analisis univariat dan bivariat dengan uji Chi Square $\left(x^{2}\right)$ dan uji fisher's exact. Nilai $\mathrm{p}<0,05$ dianggap berhubungan secara statistik. Pasien pterygium memiliki pekerjaan terbanyak yaitu di luar ruangan $(83,3 \%)$, riwayat keluarga dengan pterygium $(46,7 \%)$, riwayat merokok $(30 \%)$, riwayat tidak memakai topi $(66,7 \%)$, riwayat tidak memakai kacamata $(86,7 \%)$ dan kategori usia terbanyak adalah lansia-manula $(66,7 \%)$. Tidak terdapat hubungan antara faktor risiko pekerjaan $(p=0,086 ;$ OR 3,33 (CI 95\% 0,998-11,139)), merokok ( $p=0,784$; OR 0,74 (CI 95\% 0,252-2,175)), riwayat memakai topi $(p=0,778$; OR 0,72 (CI 95\% 0,240-2,206)), riwayat memakai kacamata $(p=1,000$; OR 0,72 (CI 95\% 0,147-3,545)) dan usia $(p=1,529$; OR 1,52 (CI $95 \%$ 0,536-4,361)) dengan kejadian pterygium. Terdapat hubungan antara faktor risiko riwayat keluarga pterygium dengan kejadian pterygium $(p=0,000)$. Penelitian ini menyimpulkan bahwa hanya faktor risiko riwayat keluarga pterygium yang berhubungan dengan kejadian pterygium di Poliklinik Mata BLUD RSU Cut Meutia, Kabupaten Aceh Utara tahun 2015.
\end{abstract}

Kata Kunci : merokok; pekerjaan; pterygium, riwayat keluarga dengan pterygium, , riwayat menggunakan topi dan kacamata 


\title{
THE CORELATION BETWEEN RISK FACTORS AND THE OCCURRENCE OF PTERYGIUM AT EYE POLICLINIC BLUD RSU CUT MEUTIA ACEH UTARA REGENCY IN 2015
}

\begin{abstract}
Pterygium is a common eye disease that occurs globally. Pterygium may cause astigmatism and also other disorders such as decreased visual acuity, chronic irritation, recurrent inflammation, double vision, and eye movement disorders and even blindness. This study aims to determine the relation between risk factors and the occurrence of pterygium at eye policlinic BLUD RSU Cut Meutia, Kabupaten Aceh Utara in 2015. This study used analytic observational method with casecontrol design. This study was conducted on September, 2015-March, 2016 and the number of sample in this study were divided into 30 patients with pterygium and 30 patients non-pterygium. The data was analyzed by using univariate and bivariate analysis by using Chi Square test $\left(\mathrm{x}^{2}\right)$ and fisher's exact test. P value $<0,05$ was considered statistically significant. Most patients with pterygium have an outdoor occupation $(83.3 \%)$, family history with pterygium $(46.7 \%)$, smoking habit $(30 \%)$, no hat $(66.7 \%)$ and eyeglasses $(86.7 \%)$ wearing, and elderly-very old age category $(66.7 \%)$. There were no relations between occupation $(\mathrm{p}=0.086$; OR 3.33 (CI 95\% 0.998-11.139)), smoking ( $\mathrm{p}=0.784$; OR 0.74 (CI 95\% 0.252-2.175)), wearing of hat ( $\mathrm{p}=0.778$; OR 0.72 (CI 95\% 0.240-2.206)) and eyeglasses ( $\mathrm{p}=1.000$; OR 0.72 (CI 95\% 0.147-3.545)) and age $(\mathrm{p}=1.529$; OR 1.52 (CI 95\% 0.536-4.361)) with pterygium. There was a relation between family history and pterygium $(p=0.000)$. The study concluded that only family history with pterygium had relation with the pterygium at eye policlinic BLUD RSU Cut Meutia, Kabupaten Aceh Utara in 2015.
\end{abstract}

Keywords: smoking; occupation; pterygium; family history; wearing of hat and eyeglasses 


\section{Pendahuluan}

Pterygium merupakan penyakit mata bagian eksternal yang umum terjadi dengan prevalensi berkisar antara $0,7 \%$ dan 33\% secara global. Penyakit ini digambarkan seperti berbentuk sayap, terdapat lesi fibrovaskular yang melintasi bagian nasal atau temporal limbus. ${ }^{1}$ Pterygium dapat menyebabkan terjadinya astigmatisme serta menimbulkan gangguan lain seperti menurunnya tajam penglihatan, iritasi kronik, inflamasi rekuren, penglihatan ganda, serta gangguan pergerakan bola mata. ${ }^{2}$ Pterygium berpotensi menyebabkan kebutaan dan mengganggu kosmetik, pada stadium lanjut memerlukan tindakan operasi untuk perbaikan visus. Pertumbuhan pterygium dipengaruhi oleh faktor-faktor risiko, penyebab dan distribusi penyakit yang berguna untuk memberikan strategi yang tepat dalam pencegahan terjadinya pterygium. ${ }^{3}$

Pterygium lebih sering ditemukan di daerah beriklim tropis dan subtropics. ${ }^{4}$ Angka prevalensi pterygium di Amerika Serikat berkisar 2\% (bagian utara) sampai 7\% (bagian selatan). ${ }^{3}$ Prevalensi pterygium dilaporkan dalam studi yang berbeda bervariasi berdasarkan usia, jenis kelamin, ras, dan geografi. Pterygium ditemukan sekitar 23,4\% dari orang kulit hitam, 23,7\% dari campuran (orang kulit hitam dan kulit putih), dan $10,2 \%$ dari orang kulit putih dalam studi mata di Barbados. Prevalensi pterygium dalam berbagai penelitian didaerah Cina, mulai dari 2,9\% di utara Cina, $14,49 \%$ di Tibet dan 33,01\% di daerah pinggiran di Cina selatan. Di Singapura, 6,9\% dari etnis Tionghoa dewasa ditemukan memiliki pterygium disalah satu matanya. ${ }^{5}$

Prevalensi pterygium nasional adalah sebesar $8,3 \%$ dengan prevalensi tertinggi ditemukan di Bali (25,2\%), diikuti Maluku $(18,0 \%)$ dan Nusa Tenggara Barat $(17,0 \%)$. Provinsi DKI Jakarta mempunyai prevalensi pterygium terendah yaitu 3,7\%, diikuti oleh
Banten 3,9\%, sedangkan prevalensi pterygium di Aceh sebesar 9,4\%.6

Kota Lhokseumawe yang merupakan salah satu kota di wilayah Provinsi Aceh dalam Negara Kesatuan Republik Indonesia menjadi salah satu kota dengan insidensi ptergium yang cukup tinggi di Aceh. Lhokseumawe menempati urutan ketiga prevalensi pterygium nasional tertinggi setelah Bireuen dan Aceh Singkil. Aceh Tenggara mempunyai prevalensi pterygium terendah yaitu 3,0\%. ${ }^{6}$ Data Badan Layanan Umum Daerah Rumah Sakit Umum (BLUD RSU) Cut Meutia Kabupaten Aceh Utara pada tahun 2013 menunjukkan 375 orang yang mendapat pelayanan kesehatan dengan pterygium. Data pada tahun 2014, menunjukkan 370 orang yang mendapat pelayanan kesehatan dengan pterygium. Data dari bulan Januari sampai April 2015 menunjukkan 139 orang yang menderita pterygium.

Data prevalensi pterygium nasional tahun 2013 dan Riskesdas Aceh 2013 menunjukkan bahwa pterygium merupakan salah satu penyakit kelainan konjungtiva dengan angka morbiditas yang tinggi dan Kota Lhokseumawe menduduki peringkat ketiga tertinggi insidensi pterygium di Provinsi Aceh. Data BLUD RSU Cut Meutia Kabupaten Aceh Utara juga menunjukkan tingginya angka prevalensi pterygium pada pasien yang mendapat pelayanan kesehatan.

Tujuan umum dari penelitian ini adalah untuk mengetahui hubungan faktor risiko dengan kejadian Pterygium di Poliklinik Mata BLUD RSU Cut Meutia, Kabupaten Aceh Utara tahun 2015.

\section{Metode}

Penelitian ini menggunakan metode observasional analitik dengan pendekatan case control. Populasi dalam penelitian ini adalah seluruh pasien di Poliklinik Mata BLUD RSU Cut Meutia Kabupaten Aceh Utara tahun 2015. Sampel dalam penelitian 
ini dibagi kedalam dua kelompok, yaitu kelompok pasien pterygium di Poliklinik Mata BLUD RSU Cut Meutia Kabupaten Aceh Utara tahun 2015 (kelompok kasus) dan kelompok pasien yang tidak menderita pterygium di Poliklinik Mata BLUD RSU Cut Meutia Kabupaten Aceh Utara tahun 2015 (kelompok kontrol) pada periode penelitian yang memenuhi kriteria penelitian. Sumber data dalam penelitian ini diperoleh dari data primer. Data primer didapatkan dengan menggunakan kuesioner. Langkah-langkah pengumpulan data adalah menjelaskan tujuan penelitian kepada responden, meminta persetujuan responden untuk diwawancarai, peneliti melakukan wawancara responden untuk mengisi kuesioner berdasarkan faktor risiko terjadinya pterygium.

Instrumen yang digunakan dalam penelitian ini adalah Kuesioner yang terbagi dalam 4 kelompok yaitu Kuesioner I yang berisi informasi tentang pengenalan tempat yang terdiri dari: kabupaten atau kodya, kecamatan, desa atau kelurahan, daerah, letak geografis, Kuesioner II yang berisi informasi tentang sosial dan demografi yang terdiri dari: nama responden, umur, jenis kelamin, suku, pendidikan, pekerjaan (meliputi lama bekerja, lokasi tempat kerja, jika diluar ruangan berapa jam sehari, apakah memakai topi dan kaca mata pelindung), aktivitas lain, dan paparan asap rokok, Kuesioner III yang berisi informasi tentang hasil pemeriksaan mata yang didapat dari data rekam medis pasien, terdiri dari: Grade dan Lokasi pterygium, Kuesioner IV yang berisi informasi tentang ada atau tidaknya riwayat pterygium dalam keluarga. $^{7}$

Analisis univariat dalam penelitian ini bertujuan untuk mendeskripsikan karakteristik setiap faktor risiko pterygium dalam bentuk tabel distribusi frekuensi. Analisis bivariat dalam penelitian ini bertujuan untuk mengidentifikasi hubungan setiap variabel dalam penelitian ini dengan pterygium menggunakan uji chi square dan uji fisher's exact dengan a 0,05 . Setelah dilakukan uji chi square dan uji fisher's exact, maka analisis data dilanjutkan dengan menghitung nilai Odds Ratio. Hasil perhitungan nilai Odds Ratio adalah untuk melihat seberapa besar proporsi pemaparan pada kelompok kasus dibandingkan dengan kelompok kontrol.

\section{Hasil Penelitian}

A. Karakteristik Faktor Risiko pada Pasien Pterygium

Distribusi faktor risiko dari 30 responden yang mengalami pterygium di Poliklinik mata BLUD RSU Cut Meutia, seperti yang tertera pada Tabel 1 .

Tabel 1. Distribusi Karakteristik Faktor Risiko pada Pasien Pterygium

\begin{tabular}{llcc}
\hline \multicolumn{2}{c}{ Distribusi Pasien } & Frekuensi (n) & Persentase (\%) \\
\hline Pekerjaan & Luar Ruangan & 25 & 83,3 \\
& Dalam Ruangan & 5 & 16,7 \\
\multicolumn{1}{c}{ Riwayat Keluarga } & & \\
& Ya & 14 & 46,7 \\
& Tidak & 16 & 53,3 \\
Merokok & & & 30 \\
& Ya & 9 & 70
\end{tabular}


Riwayat Memakai Topi

Tidak

Ya

Riwayat memakai kacamata

Tidak

Ya

Usia

$$
\begin{aligned}
& \text { Lansia-Manula } \\
& \text { Remaja-Dewasa }
\end{aligned}
$$

Pasien pterygium memiliki faktor risiko pekerjaan yang terbanyak berupa pekerjaan di luar ruangan yaitu 25 orang (83,3\%), pasien yang memiliki riwayat keluarga dengan pterygium yaitu 14 orang $(46,7 \%)$, kebanyakan dari pasien pterygium yang didapat tidak merokok yaitu 21 orang $(70,0 \%)$. Sebagian besar pasien pterygium tidak memakai topi saat berada di luar ruangan yaitu sebanyak 20 orang $(66,7 \%)$, penggunaan kacamata saat berada di luar ruangan hanya terdapat pada sebagian kecil pasien pterygium sedangkan 26 orang
20
66,7
10
33,3

\begin{tabular}{|c|c|c|}
\hline Distribusi Pasien & Frekuensi (n) & Persentase (\%) \\
\hline \multicolumn{3}{|l|}{ Pekerjaan } \\
\hline Luar Ruangan & 18 & 60,0 \\
\hline Dalam Ruangan & 12 & 40,0 \\
\hline \multicolumn{3}{|l|}{ Riwayat Keluarga } \\
\hline$Y a$ & 0 & 0 \\
\hline Tidak & 30 & 100 \\
\hline \multicolumn{3}{|l|}{ Merokok } \\
\hline Ya & 11 & 36,7 \\
\hline Tidak & 19 & 63,3 \\
\hline \multicolumn{3}{|l|}{ Riwayat Memakai Topi } \\
\hline Tidak & 22 & 73,3 \\
\hline Ya & 8 & 26,7 \\
\hline \multicolumn{3}{|l|}{ Riwayat memakai kacamata } \\
\hline Tidak & 27 & 90,0 \\
\hline Ya & 3 & 10,0 \\
\hline \multicolumn{3}{|l|}{ Usia } \\
\hline Lansia-Manula & 17 & 56,7 \\
\hline Remaja-Dewasa & 13 & 43,3 \\
\hline
\end{tabular}

Tabel 2. Distribusi Karakteristik Faktor Risiko pada Pasien Non-Pterygium 
Pasien non-pterygium memiliki faktor risiko pekerjaan terbanyak yaitu pekerjaan di luar ruangan sebanyak 18 orang $(60,0 \%)$, seluruh pasien tidak memiliki riwayat keluarga dengan pterygium yaitu 30 orang $(100 \%)$, sebagian besar pasien tidak merokok yaitu 19 orang $(63,3 \%)$, kebanyakan pasien tidak menggunakan topi dan kacamata saat beraktivitas di luar ruangan yaitu berturut-turut sebanyak 22 orang $(73,3 \%)$ dan 27 orang $(90,0 \%)$, pasien didominasi oleh kelompok usia lansiamanula yaitu sebanyak 17 orang $(56,7 \%)$.

C. Hubungan faktor risiko pekerjaan dengan kejadian pterygium

Tabel 3. Hubungan Faktor Risiko Pekerjaan dengan Kejadian Pterygium di Poliklinik Mata BLUD RSU Cut Meutia Tahun 2015

\begin{tabular}{|c|c|c|c|c|c|c|c|c|c|}
\hline & & \multicolumn{4}{|c|}{ Kejadian Pterygium } & \multirow[b]{3}{*}{ Total } & \multirow[b]{3}{*}{$\%$} & \multirow[b]{3}{*}{$p$ value } & \multirow[b]{3}{*}{ OR } \\
\hline & & \multirow{2}{*}{ Pterygium } & \multicolumn{3}{|c|}{ Non- } & & & & \\
\hline & & & $\%$ & Pterygium & $\%$ & & & & \\
\hline \multirow{4}{*}{ Pekerjaan } & Luar & & & & & & & \multirow{4}{*}{0,086} & \multirow{4}{*}{3,333} \\
\hline & Ruangan & 25 & 83,3 & 18 & 60 & 43 & 71,7 & & \\
\hline & Dalam & & & & & & & & \\
\hline & Ruangan & 5 & 16,7 & 12 & 40 & 17 & 28,3 & & \\
\hline \multicolumn{2}{|c|}{ Total } & 30 & 100 & 30 & 100 & 60 & 100 & & \\
\hline
\end{tabular}

Pasien pterygium paling banyak memiliki pekerjaan di luar ruangan yaitu sebanyak 25 orang $(83,3 \%)$. Pasien nonpterygium paling banyak memiliki pekerjaan di luar ruangan adalah sebanyak 18 orang $(60,0 \%)$. Hasil uji Chi Square $\left(X^{2}\right)$ didapatkan nilai $\mathrm{p}$ value sebesar $0,086(p>\mathrm{a})$. Hal ini menunjukkan Ho diterima dan Ha ditolak yaitu tidak terdapat hubungan antara faktor risiko pekerjaan dengan kejadian pterygium di poliklinik mata BLUD RSU Cut Meutia Tahun 2015.
Hasil perhitungan didapatkan nilai Odds Ratio $(\mathrm{OR})=3,333$. Nilai $\mathrm{OR}>1$, maka dapat disimpulkan bahwa pekerjaan di luar ruangan merupakan faktor risiko terjadinya pterygium. Nilai OR tersebut menunjukkan bahwa risiko untuk mengalami kejadian pterygium 3,3 kali (77\%) pada pasien yang memiliki pekerjaan di luar ruangan daripada pasien yang memiliki pekerjaan di dalam ruangan.

D. Hubungan faktor risiko riwayat keluarga pterygium dengan kejadian pterygium

Tabel 4. Hubungan Faktor Risiko Riwayat Keluarga Pterygium dengan Kejadian Pterygium di Poliklinik Mata BLUD RSU Cut Meutia Tahun 2015

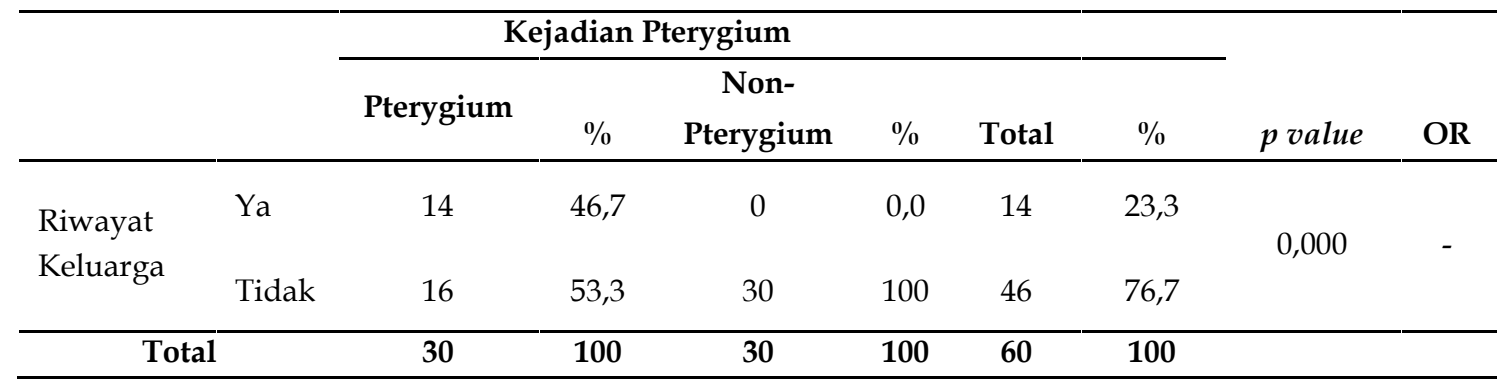

Pasien pterygium yang memiliki riwayat keluarga dengan pterygium yaitu sebanyak 14 orang $(46,7 \%)$ dan yang tidak memiliki riwayat keluarga dengan 
pterygium yaitu sebanyak 16 orang $(53,3 \%)$.

Semua pasien non-pterygium tidak memiliki riwayat keluarga dengan pterygium (100\%). Hasil uji Chi Square $\left(X^{2}\right)$ didapatkan nilai $p$ value sebesar $0,000(p<\alpha)$.
Hal ini menunjukkan Ho ditolak dan Ha diterima yaitu terdapat hubungan antara faktor risiko riwayat keluarga pterygium dengan kejadian pterygium di poliklinik mata BLUD RSU Cut Meutia Tahun 2015.

E. Hubungan faktor risiko merokok dengan kejadian pterygium

Tabel 5. Hubungan Faktor Risiko Merokok dengan Kejadian Pterygium di Poliklinik Mata BLUD RSU Cut Meutia Tahun 2015

\begin{tabular}{|c|c|c|c|c|c|c|c|c|c|}
\hline & & & jadiar & terygium & & & & & \\
\hline & & Dtonsurinu & & Non- & & & & & \\
\hline & & 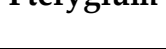 & $\%$ & Pterygium & $\%$ & Total & $\%$ & p value & OR \\
\hline & $\mathrm{Ya}$ & 9 & 30,0 & 11 & 36,7 & 20 & 33,3 & & \\
\hline Merokok & & & & & & & & 0,784 & 0,740 \\
\hline & Tidak & 21 & 70,0 & 19 & 63,3 & 40 & 66,7 & & \\
\hline & & 30 & 100 & 30 & 100 & 60 & 100 & & \\
\hline
\end{tabular}

Pasien pterygium yang memiliki riwayat merokok yaitu sebanyak 9 orang $(30,0 \%)$ dan yang tidak memiliki riwayat merokok yaitu sebanyak 21 orang $(70,0 \%)$. Pasien non-pterygium yang memiliki riwayat merokok adalah sebanyak 11 orang $(36,7 \%)$ dan yang tidak memiliki riwayat merokok adalah sebanyak 19 orang $(63,3 \%)$. Hasil uji Chi Square $\left(\mathrm{X}^{2}\right)$ didapatkan nilai $p$ value sebesar 0,784 $(p>$ a). Hal ini menunjukkan Ho diterima dan Ha ditolak yaitu tidak terdapat hubungan antara faktor risiko merokok dengan kejadian pterygium di poliklinik mata BLUD RSU Cut Meutia Tahun 2015.

Hasil perhitungan didapatkan nilai Odds Ratio $(\mathrm{OR})=0,740$. Nilai $\mathrm{OR}<1$ maka dapat disimpulkan bahwa merokok bukan merupakan faktor risiko terjadinya pterygium. Nilai OR tersebut memiliki pengertian bahwa risiko untuk mengalami kejadian pterygium 0,7 kali (42\%) pada pasien yang memiliki riwayat merokok daripada pasien yang tidak memiliki riwayat merokok.

F. Hubungan faktor risiko memakai topi dengan kejadian pterygium

Tabel 6. Hubungan Faktor Risiko Memakai Topi dengan Kejadian Pterygium di Poliklinik Mata BLUD RSU Cut Meutia Tahun 2015

\begin{tabular}{|c|c|c|c|c|c|c|c|c|c|}
\hline & & & jadiar & terygium & & & & & \\
\hline & & Dtoun & & Non- & & & & & \\
\hline & & 1 terygitum & $\%$ & Pterygium & $\%$ & Total & $\%$ & p value & OR \\
\hline Riwayat & Tidak & 20 & 66,7 & 22 & 73,3 & 42 & 70,0 & & \\
\hline Memakai & & & & & & & & 0,778 & 0,727 \\
\hline Topi & Ya & 10 & 33,3 & 8 & 26,7 & 18 & 30,0 & & \\
\hline To & & 30 & 100 & 30 & 100 & 60 & 100 & & \\
\hline
\end{tabular}

Pasien pterygium paling banyak tidak memiliki riwayat memakai topi yaitu sebanyak 20 orang $(66,7 \%)$. Pasien nonpterygium paling banyak tidak memiliki 
riwayat memakai topi yaitu sebanyak 22 orang (73,3\%). Hasil uji Chi Square $\left(\mathrm{X}^{2}\right)$ didapatkan nilai $p$ value sebesar 0,778 $(p>a)$. Hal ini menunjukkan Ho diterima dan Ha ditolak yaitu tidak terdapat hubungan antara faktor risiko riwayat memakai topi dengan kejadian pterygium di poliklinik mata BLUD RSU Cut Meutia Tahun 2015.

Hasil perhitungan didapatkan nilai Odds Ratio $(\mathrm{OR})=0,727$. Nilai $\mathrm{OR}<1$ maka dapat disimpulkan bahwa riwayat memakai topi bukan merupakan faktor risiko terjadinya pterygium. Nilai $\mathrm{OR}$ tersebut menunjukkan bahwa risiko untuk mengalami kejadian pterygium 0,7 kali $(42 \%)$ pada pasien yang tidak memiliki riwayat memakai topi daripada pasien yang memiliki riwayat memakai topi.

G. Hubungan faktor risiko memakai kacamata dengan kejadian pterygium

Tabel 7. Hubungan Faktor Risiko Memakai Kacamata dengan Kejadian Pterygium di Poliklinik Mata BLUD RSU Cut Meutia Tahun 2015

\begin{tabular}{|c|c|c|c|c|c|c|c|c|c|}
\hline & & \multicolumn{4}{|c|}{ Kejadian Pterygium } & \multirow[b]{3}{*}{ Total } & \multirow[b]{3}{*}{$\%$} & \multirow[b]{3}{*}{ p value } & \multirow[b]{3}{*}{ OR } \\
\hline & & \multirow{2}{*}{ Pterygium } & \multicolumn{3}{|c|}{ Non- } & & & & \\
\hline & & & $\%$ & Pterygium & $\%$ & & & & \\
\hline Riwayat & Tidak & 26 & 86,7 & 27 & 90,0 & 53 & 88,3 & \multirow{3}{*}{1,000} & \multirow{3}{*}{0,722} \\
\hline Memakai & & & & & & & & & \\
\hline Kacamata & Ya & 4 & 13,3 & 3 & 10,0 & 7 & 11,7 & & \\
\hline \multicolumn{2}{|c|}{ Total } & 30 & 100 & 30 & 100 & 60 & 100 & & \\
\hline
\end{tabular}

Pasien pterygium paling banyak tidak memiliki riwayat memakai kacamata yaitu sebanyak 26 orang $(86,7 \%)$. Pasien nonpterygium paling banyak tidak memiliki riwayat memakai kacamata yaitu sebanyak 27 orang $(90,0 \%)$. Hasil uji Fisher's Exact didapatkan nilai $p$ value $1,000(p>$ a). Hal ini menunjukkan Ho diterima dan Ha ditolak yaitu tidak terdapat hubungan antara faktor risiko riwayat memakai kacamata dengan kejadian pterygium di poliklinik mata BLUD RSU Cut Meutia Tahun 2015.
Hasil perhitungan didapatkan nilai Odds Ratio $(\mathrm{OR})=0,722$. Nilai $\mathrm{OR}<1$ maka dapat disimpulkan bahwa riwayat memakai kacamata bukan merupakan faktor risiko terjadinya pterygium. Nilai OR tersebut memiliki pengertian bahwa risiko untuk mengalami kejadian pterygium 0,7 kali $(42 \%)$ pada pasien yang tidak memiliki riwayat memakai kacamata daripada pasien yang memiliki riwayat memakai kacamata.

H. Hubungan faktor risiko usia dengan kejadian pterygium

Tabel 8. Hubungan Faktor Risiko Usia dengan Kejadian Pterygium di Poliklinik Mata BLUD RSU Cut Meutia Tahun 2015

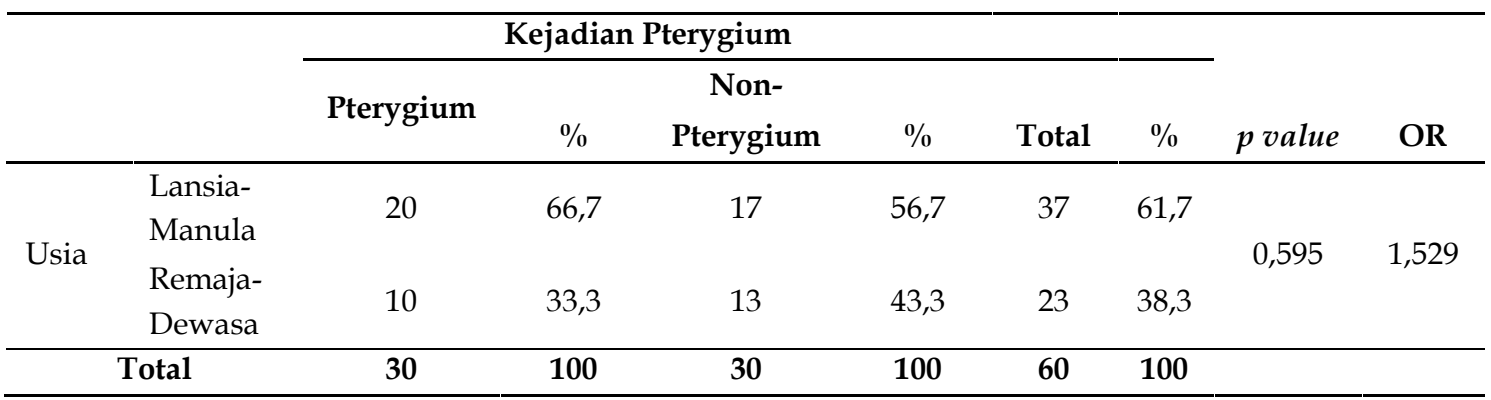


Pasien pterygium paling banyak terdapat pada kategori usia lansia-manula yaitu sebanyak 20 orang (66,7\%). Pasien non-pterygium paling banyak terdapat pada kategori usia lansia-manula yaitu sebanyak 17 orang $(56,7 \%)$. Hasil uji Chi Square $\left(\mathrm{X}^{2}\right)$ didapatkan nilai $p$ value sebesar 0,595 $(p>\alpha)$. Hal ini menunjukkan Ho diterima dan $\mathrm{Ha}$ ditolak yaitu tidak terdapat hubungan antara faktor risiko usia dengan kejadian pterygium di poliklinik mata BLUD RSU Cut Meutia Tahun 2015.

Hasil perhitungan didapatkan nilai Odds Ratio $(\mathrm{OR})=1,529$. Nilai $\mathrm{OR}>1$ maka dapat disimpulkan bahwa usia lansiamanula merupakan faktor risiko terjadinya pterygium. Nilai OR tersebut menunjukkan bahwa risiko untuk mengalami kejadian pterygium 1,5 kali (60\%) pada pasien dengan kategori usia lansia-manula daripada kategori usia remaja-dewasa.

\section{Pembahasan}

\section{A. Gambaran Faktor Risiko Pekerjaan}

Hasil penelitian ini pada 30 responden yang mengalami pterygium didapatkan bahwa jenis pekerjaan terbanyak adalah di luar ruangan yaitu sebesar 83,3\%. Tiga puluh responden yang tidak mengalami pterygium didapatkan bahwa jenis pekerjaan terbanyak adalah di luar ruangan yaitu sebesar $60,0 \%$. Hal ini sesuai dengan hasil penelitian Gazzard et al., (2002) menunjukkan bahwa 10,9\% pekerjaan yang melibatkan aktivitas di luar ruangan lebih dikaitkan dengan pterygium daripada 7,6\% pekerjaan yang melibatkan aktivitas di dalam ruangan. Studi telah menunjukkan bahwa menghabiskan waktu yang cukup lama di luar ruangan telah menyebabkan peningkatan risiko pterygium. Hal ini dikaitkan dengan paparan ultraviolet (UV) kumulatif yang berperan penting. ${ }^{9}$

Pterygium biasanya terlihat di negaranegara dengan eksposur yang relatif tinggi untuk radiasi ultraviolet. Kekeringan mata, angin, kelembaban yang rendah dan pekerjaan dengan tingginya pajanan terhadap zat iritan juga berpengaruh pada peningkatan insidensi pterygium. Pasien yang bekerja di luar ruangan yang terutama berhubungan dengan beton memiliki sepuluh kali lipat peningkatan risiko pterygium, sedangkan orang-orang yang bekerja di daerah berpasir memiliki beberapa ratus kali lipat peningkatan risiko berkembangnya pterygium dibandingkan dengan mereka yang bekerja di dalam ruangan. ${ }^{10}$

B. Gambaran Faktor Risiko Riwayat Keluarga

Hasil penelitian ini pada 30 responden yang mengalami pterygium didapatkan bahwa $46,7 \%$ responden memiliki riwayat keluarga dengan pterygium, sedangkan $53,3 \%$ responden tidak memiliki riwayat keluarga dengan pterygium. Tiga puluh responden yang tidak mengalami pterygium didapatkan bahwa 100\% responden tidak memiliki riwayat keluarga dengan pterygium. Hal ini sesuai dengan penelitian Anguria, Ntuli \& Carmichael (2011) yang menyatakan bahwa terdapat riwayat keluarga positif pterygium pada 36\% kelompok kasus dan $10 \%$ pada kelompok kontrol. Riwayat positif pterygium hampir 5 kali lebih sering didapat dalam kelompok kasus daripada kelompok kontrol. Penelitian telah mengakui bahwa kecenderungan bawaan berperan penting dalam pembentukan pterygium. Faktor genetik telah dilaporkan secara autosomal dominan berdasarkan studi dari satu atau dua anggota keluarga. ${ }^{11}$

\section{Gambaran Faktor Risiko Merokok \\ Penelitian yang dilakukan di poliklinik mata BLUD RSU Cut Meutia didapatkan hasil dari 30 responden yang mengalami}


pterygium bahwa $70,0 \%$ pasien pterygium tidak merokok, sedangkan 30,0\% lainnya memiliki kebiasaan merokok. Terdapat $63,3 \%$ pasien non-pterygium yang tidak merokok dan sisanya yaitu $36,7 \%$ mengaku memiliki kebiasaan merokok. Penelitian yang dilakukan Laszuarni (2010) juga menyatakan hasil yang sama bahwa lebih banyak responden pterygium yang tidak merokok dibandingkan dengan yang memiliki riwayat merokok. Hasil dari penelitian tersebut didapatkan 12,4\% responden pterygium memiliki riwayat merokok dan 21,0\% tidak memiliki riwayat merokok. Merokok dianggap sebagai salah satu faktor risiko dalam pembentukan gejala mata kering dan asap rokok mengandung banyak senyawa yang dapat mengiritasi mata dan bersifat racun. Selain dapat mengiritasi mata, asap rokok juga berperan dalam mekanisme iskemik atau oksidatif yang melibatkan produksi radikal bebas dan penurunan mekanisme antioksidan. ${ }^{13}$

Iritasi mata yang terjadi secara berulang menyebabkan lengkung neural diaktivasi secara berlebihan dan menyebabkan perubahan sekresi air mata. Ditandai dengan sekresi sel $\mathrm{T}$ yang teraktivasi dan sitokin dalam air mata. Keberadaan sitokin dalam air mata menyebabkan inflamasi pada permukaan okuler yang akan mengganggu penyampaian sinyal sensoris dari permukaan mata sehingga sekresi basal air mata menurun. Pada kelenjar lakrimalis baik secara langsung maupun tidak langsung juga mengalami kerusakan. Keadaan ini menyebabkan penurunan sekresi air mata dan inflamasi tersebut tidak dapat diatasi oleh sistem pertahanan mata yang normal, walaupun secara fisiologis di dalam air mata mengandung komponen anti inflamasi. Inflamasi tersebut juga menyebabkan disfungsi dari sistem air mata sehingga terjadi gangguan drainase yang menyebabkan iritasi tidak terkontrol dan peningkatan aktivasi dari limfosit T. Selain itu, sitokin dan mediator inflamasi lainnya juga menyebabkan peningkatan jumlah sel $\mathrm{T}$ yang diaktivasi, jumlah produksi substansi inflamasi dan jumlah kerusakan jaringan. ${ }^{14}$

\section{Gambaran Faktor Risiko Pemakaian Topi dan Kacamata}

Penelitian yang dilakukan di poliklinik mata BLUD RSU Cut Meutia mendapatkan hasil dari 30 responden yang mengalami pterygium berupa $66,7 \%$ responden tidak menggunakan topi saat beraktivitas di luar ruangan dan $33,3 \%$ responden mengaku menggunakan topi sedangkan pada 30 responden non-pterygium didapatkan $73,3 \%$ responden tidak menggunakan topi dan sisanya $26,7 \%$ menggunakannya. Dari kajian di atas didapatkan bahwa lebih banyak responden yang tidak menggunakan topi saat beraktivitas di luar ruangan. Hal tersebut juga terjadi pada penggunaan kacamata pada responden. Sebanyak 86,7\% responden pterygium tidak menggunakan kacamata saat beraktivitas di luar ruangan dan hanya $13,3 \%$ yang mengaku menggunakannya. Hal serupa juga terjadi pada pasien non-pterygium dengan 90,0\% responden mengaku tidak menggunakan kacamata dan 10,0\% sisanya menggunakan kacamata.

Menurut penelitian Mackenzie et al., (1992) dalam Meseret, Bejiga \& Ayalew (2008), tingginya persentase jumlah pasien yang tidak menggunakan topi ataupun kacamata berkaitan dengan adanya hubungan yang kuat antara paparan sinar UV dan pembentukan dari pterygium. Penelitian juga mengidentifikasi adanya persentase risiko yang lebih besar pada orang yang tidak pernah menggunakan kacamata ataupun topi.

\section{E. Gambaran Faktor Risiko Usia}

Kejadian pterygium terkait faktor risiko usia dalam penelitian yang dilakukan di poliklinik mata BLUD RSU Cut Meutia 
didapatkan kelompok usia remaja-dewasa pada kelompok kasus sebanyak 33,3\% dan $66,7 \%$ didapatkan pada kelompok usia lansia-manula. Hal tersebut menyimpulkan bahwa kejadian pterygium semakin meningkat dengan adanya peningkatan usia. Serupa hal nya dengan hasil penelitian pada kelompok kontrol didapatkan bahwa kelompok usia remaja-dewasa memiliki persentase sebesar 43,3\% dan kelompok usia lansia-manula memiliki persentase sebesar $56,7 \%$. Penelitian yang dilakukan Liu et al., (2013) mendukung hasil dari penelitian di atas dengan adanya bukti hasil penelitiannya berupa adanya peningkatan prevalensi pterygium pada kelompok usia yang lebih tua, $11 \%$ pada usia $40-49$ tahun, $15,6 \%$ pada usia 50-59 tahun dan $20,1 \%$ pada usia 60-69 tahun sedangkan pada usia $>70$ tahun didapatkan prevalensi sebesar $20,2 \%$. Proses pertambahan usia menyebabkan kerusakan mata akibat radiasi UV terakumulasi, sehingga prevalensi pterygium lebih tinggi pada orang yang lebih tua daripada orang yang lebih muda. ${ }^{5}$

Data Riskesdas (2013) menunjukkan pembuktian dari teori di atas, dengan data penderita pterygium usia 0-4 dan 5-14 tahun memiliki prevalensi sebesar 0,8\%, 15-24 tahun dengan prevalensi 2,0\%, 25-34 tahun sebesar $5,4 \%$ dan terus meningkat prevalensinya hingga usia $>75$ tahun memiliki prevalensi sebesar $36,4 \%$.

\section{F. Hubungan Faktor Risiko Pekerjaan dengan Kejadian Pterygium}

Data yang diperoleh dari hasil uji statistik menunjukkan bahwa tidak terdapat hubungan antara faktor risiko pekerjaan dengan kejadian pterygium di poliklinik mata BLUD RSU Cut Meutia Tahun 2015 (p value $=0,086$ ). Hasil yang sama juga didapat pada penelitian Tano et al., (2013) di Jepang terhadap 2.312 responden, hasil penelitian tersebut menunjukkan bahwa tidak ada perbedaan yang signifikan terkait dengan riwayat pekerjaan di luar ruangan pada responden dengan atau tanpa pterygium.

Beberapa mekanisme molekuler diaktifkan oleh paparan UV, termasuk stres oksidatif dan sinyal reseptor faktor pertumbuhan reseptor sinyal. Hal ini menyebabkan produksi dari berbagai faktor, seperti sitokin proinflamasi dan matriks metalloproteinase muncul untuk mempromosikan pertumbuhan pterygium. Faktor pertumbuhan jaringan ikat dan faktor pertumbuhan endotel vaskular muncul pada epitel pterygium. ${ }^{19}$ Secara teori lamanya aktivitas ataupun pekerjaan yang berada diluar ruangan juga berpengaruh dalam peningkatan insidensi pterygium, temuan ini membantu untuk menunjukkan hubungan yang kuat antara radiasi sinar UV dan insidensi pterygium. ${ }^{20}$

Data yang diperoleh dari hasil penelitian di poliklinik mata BLUD RSU Cut Meutia Tahun 2015 didapatkan nilai Odds Ratio $(\mathrm{OR})=3,333$. Hal tersebut mengandung arti bahwa untuk mengalami kejadian pterygium 3,3 kali lebih besar pada pasien yang memiliki pekerjaan di luar ruangan daripada pasien yang memiliki pekerjaan di dalam ruangan.

\section{G. Hubungan Faktor Risiko Riwayat Keluarga Pterygium dengan Kejadian Pterygium}

Data yang diperoleh dari hasil uji statistik menunjukkan bahwa terdapat hubungan antara faktor risiko riwayat keluarga pterygium dengan kejadian pterygium di poliklinik mata BLUD RSU Cut Meutia Tahun 2015. Hubungan faktor risiko riwayat keluarga pteryium dengan kejadian pterygium pada penelitian ini memiliki $\mathrm{p}$ value sebesar $0,000(\mathrm{p}<\mathrm{\alpha})$. Hasil penelitian di atas didukung oleh penelitian yang telah dilakukan oleh Laszuarni (2010) di Kabupaten Langkat dengan jumlah responden sebesar 2.419 orang, didapatkan hasil bahwa terdapat hubungan antara 
faktor risiko riwayat keluarga pterygium dengan kejadian pterygium ( $\mathrm{p}$ value $=0,005$ $<a=0,05)$. Riwayat keluarga dengan pterygium, kemungkinan diturunkan autosomal dominan.

\section{H.Hubungan Faktor Risiko Merokok dengan Kejadian Pterygium}

Hasil dari penelitian di poliklinik mata BLUD RSU Cut Meutia didapatkan sebagian besar pasien pterygium tidak merokok dan hasil uji statistik menunjukkan bahwa tidak terdapat hubungan antara faktor risiko merokok dengan kejadian pterygium di poliklinik mata BLUD RSU Cut Meutia Tahun 2015. P value pada penelitian ini adalah sebesar 0,784 $(p>a)$. Hasil tersebut sesuai dengan penelitian Jiao et al., (2014) yang juga menyatakan bahwa tidak terdapat hubungan antara kebiasaan merokok dengan pterygium ( $\mathrm{p}$ value $=0,811$ ).

iritasi yang disebabkan oleh debu mengakibatkan lisis lapisan lipid pada film air mata dan prosesnya terus berlanjut jika terpajan dalam waktu yang lama sehingga mempengaruhi permukaan konjungtiva terutama daerah limbus dan mengakibatkan terangsangnya epitel limbus. ${ }^{21}$ Penurunan produksi cairan air mata akibat paparan zat iritan secara kronik dapat menyebabkan metaplasia dan penurunan jumlah sel goblet pada epitel konjungtiva. Hal ini terjadi akibat aktivasi sel $\mathrm{T}$ dan sel NK sehingga terjadi pelepasan interferon $\gamma(\mathrm{IFN}-\gamma)$ dimana sitokin ini terlibat pada hampir seluruh respon imun dan inflamasi. Interferon $\gamma$ dikenal memiliki potensi untuk meningkatkan regulasi protein yang berhubungan dengan diferensiasi epitel konjungtiva (conjunctival epithelial differentiation-related proteins). Interferon $\mathrm{V}$ dilaporkan mampu meningkatkan trankripsi RNA yang mengkode prekursor keratinisasi. ${ }^{22}$

Hasil perhitungan statistik didapatkan nilai Odds Ratio $(\mathrm{OR})=0,740$. Hal tersebut memiliki arti bahwa risiko untuk mengalami kejadian pterygium 0,7 kali lebih besar pada pasien yang memiliki riwayat merokok daripada pasien yang tidak memiliki riwayat merokok.

I. Hubungan Faktor Risiko Pemakaian Topi atau Kacamata dengan Kejadian

Pterygium

Berdasarkan hasil penelitian ini didapatkan bahwa sebagian besar responden penelitian tidak menggunakan topi atau kacamata. Hasil penelitian statistik di poliklinik mata BLUD RSU Cut Meutia didapatkan bahwa tidak terdapat hubungan antara faktor risiko riwayat memakai topi atau kacamata dengan kejadian pterygium di poliklinik mata BLUD RSU Cut Meutia Tahun 2015 dengan masing-masing $\mathrm{p}$ value adalah 0,778 dan 1,000. Sejalan dengan penelitian Laszuarni (2010) bahwa tidak terdapat adanya pengaruh pada pemakaian topi dengan kejadian pterygium $(\mathrm{p}$ value $=$ $0,636)$ dan pemakaian kacamata berpengaruh untuk tidak terjadinya pterygium ( $\mathrm{p}$ value $=0,007$ ).

Penggunaan kacamata hitam dan topi bertepi untuk menghindari paparan sinar matahari yang tidak perlu dan iritasi angin kencang sangat penting untuk menurunkan insidensi pterygium. ${ }^{5}$ Hasil perhitungan didapatkan nilai Odds Ratio (OR) riwayat memakai kacamata dan riwayat memakai topi masing-masing adalah 0,722 dan 0,727. Nilai OR < 1 maka dapat disimpulkan bahwa riwayat memakai kacamata dan topi bukan merupakan faktor risiko terjadinya pterygium. Nilai tersebut mengisyaratkan bahwa untuk mengalami kejadian pterygium 0,7 kali lebih besar pada pasien yang tidak memiliki riwayat memakai kacamata dan topi daripada pasien yang memiliki riwayat memakai kacamata dan topi. 


\section{J. Hubungan Faktor Risiko Usia dengan Kejadian Pterygium}

Data yang diperoleh dari hasil penelitian dan telah diuji dengan uji statistik menunjukkan tidak terdapat hubungan antara faktor risiko usia dengan kejadian pterygium di poliklinik mata BLUD RSU Cut Meutia Tahun 2015 ( $\mathrm{p}$ value $=0,595$ ). Hasil analisis diperoleh pula rasio prevalensi sebesar 1,529 artinya untuk mengalami kejadian pterygium 1,5 kali lebih besar pada pasien dengan kategori usia lansia-manula daripada kategori usia remaja-dewasa. Hasil penelitian di atas berbeda dengan hasil penelitian yang telah dilakukan oleh Lung et al., (2013) yang mendapatkan hasil bahwa usia memiliki hubungan yang signifikan dalam terjadinya pterygium $(p<0,0001)$. Hasil survei ini sesuai dengan gagasan bahwa prevalensi pterygium meningkat dengan peningkatan usia dan mungkin dikaitkan dengan akumulasi paparan UV. ${ }^{1}$

\section{Kesimpulan dan Saran}

Kesimpulan dalam penelitian ini adalah hanya faktor risiko riwayat keluarga pterygium yang berhubungan dengan kejadian pterygium di Poliklinik Mata BLUD RSU Cut Meutia, Kabupaten Aceh Utara tahun 2015.

Saran bagi individu yang masih sehat diharapkan dapat melakukan pencegahan agar angka kejadian pterygium tidak meningkat. Bagi pasien pterygium diharapkan dapat mengetahui dan lebih peduli terhadap faktor risiko pencetus ataupun yang memperberat keadaan pterygium. Bagi tenaga kesehatan diharapkan agar dapat meningkatkan perannya dalam memberikan edukasi kepada masyarakat tentang faktor risiko pterygium. Bagi dinas kesehatan diharapkan untuk terus menguatkan upaya promotif dan preventif terhadap penyakit pterygium.

\section{Daftar Pustaka}

1. Jiao, W, Chengchao, $Z$, Ting, $W$, Shaoyuan, Y, Hongsheng, B, Liping, L, Yan, L \& Lihua, W. Prevalence and risk factors for pterygium in rural older adults in Shandong Province of China: A Cross-Sectional Study, Hindawi Publishing Corporation BioMed Research International 2014: 1.

2. Emilia, E. Third grade pterygium of a farmer, Fakultas Kedokteran Universitas Lampung. 2014.

3. Shintya, D, Rukiah, S, Junaedi, S, Noor, $\mathrm{S}$. The profile of tear mucin layer and impression cytology in pterygium patients, Jurnal Oftalmologi Indonesia 2010; 7 (4): 139.

4. Fengqing, L. Epidemiology of pterygium in aged rural population of Beijing, China. 2010/

5. Zhong, Hua, Xueping, C, Tao, W, Xianchai, L, Xun, L, Jun, L, Ning, C, Juanjuan, L, Xiaodan, S, Yongming, $\mathrm{Y}$, Minbin, $Y$, Yuansheng, Y. Prevalence of and risk factors for pterygium in rural adult Chinese populations of the Bai Nationality in Dali: The Yunnan minority eye study, Investigative Ophthalmology \& Visual Science 2012; $53: 6617-6621$.

6. Riskesdas 2013. Riset Kesehatan Dasar 2013. Badan Penelitian dan Pengembangan Kesehatan, Kementrian Kesehatan RI 2013.

7. Laszuarni. Prevalensi pterygium di Kabupaten Langkat', tesis, dokter spesialis mata Fakultas Kedokteran Universitas Sumatera Utara. 2010.

8. Gazzard, G, S-M, Saw, M, Farook, D, Koh, D, Widjaja, S-E, Chia, C-Y, Hong \& DTH, Tan. Pterygium in Indonesia: prevalence, severity and risk factors, British J Ophthalmol 2002: 1343.

9. Lu, P \& Chen, XM. Prevalence and risk factors of pterygium, Int J Ophthalmol 2009. 2009; 2 (1): 82-85. 
10. Taylor, H. Pterygium, Kugler Publication/The Hague/The

Netherland 2000: 18, 41.

11. Anguria, P, Ntuli, S \& Carmichael, T. Relationships of heredity and dry eye with pterygia in black African patients, The South African Medical Journal 2011; 101 (2): 110.

12. Anguria, P, Ntuli, S, Interewicz, B \& Carmichael, T. Traditional eye medication and pterygium occurrence in Limpopo Province, The South African Medical Journal 2012; 102 (8).

13. Yoon, KC, Byoung, YS \& Seong, S. Effects of smoking on tear film and ocular surface, Korean J Ophthalmol 2005; 19: 18-22.

14. Wilson, SE. Inflammation : A Unifying Theory For the Origin of Dry Eye Syndrome, P\&T Digest: A PeerReviewed Compendium of Formulary Considerations. 2003;12: 14-18.

15. Mackenzie, FD, Hirst, LW, Battistutta D, Green A. Risk analysis in the development of ptergia, Ophthalmology 1992: 1056-1061.

16. Meseret, A, Bejiga, A \& Ayalew, M. Prevalence of pterygium in a rural community of Meskan District, Southern Ethiopia, Ethiop. J. Health Dev 2008: 191-194.

17. Liu, Lei, Jingyang, W, Jin, G, Zhe, Y \& Desheng, H. Geographical prevalence and risk factors for pterygium: a systematic review and meta-analysis, BMJ Open 2013: 1,5.
18. Tano, T, Ono K, Hiratsuka Y, Otani K, Sekiguchi M, Konno S. et al. Prevalence of pterygium in a population in Northern Japan: the locomotive syndrome and health outcome in aizu cohort study, Acta Ophthalmologica 2013:91(3): e232-6.

19. Sheppard, J, Mansur, A, Comstock, TL, Hovanesian, JA. An update on the surgical management of pterygium and the role of loteprednol etabonate ointment, Dovepress Journal: clinical ophthalmology. Jun 13; 8: 1105-18.

20. Fine IH, Daniel, M. Minimally Invasive Ophthalmic Surgery, Springer Science \& Business Media 2010: 88, 94.

21. Dharmawan SA. Prevalensi pterygium dan faktor-faktor yang berhubungan di kalangan pekerja pabrik PT $X$ karawang - Jawa Barat 2005, tesis, Program Studi Kedokteran Kerja, Pasca Sarjana FK-UI 2005: 9 - 10.

22. De Paive, C, et al. Dry-Eye Induced Conjunctival Epithelial Squamous Metaplasia is Modulated by Interferon$\gamma$, Investigate Ophthalmology \& Visual Science. 48(6): 2553-60

23. Lung, CC, Hsiung, LC, Lun, WP, Chang, WP, Hsien, CT \& Huei, WH. The epidemiology of patients with pterygium in southern Taiwanese adults: The Chiayi survey, Taiwan Journal Ophthalmology 2013; 3(2): 5861. 